\title{
PENGARUH METODE PEMBELAJARAN TARI BAMBU TERHADAP HASIL BELAJAR SISWA PADA MATA PEMBELAJARAN IPA DI PENDIDIKAN DASAR
}

\author{
Sri Enggar Kencana Dewi ${ }^{1 \star}$, Ratih Purnama Pertiwi ${ }^{2}$ \\ ${ }^{1}$ STKIP Nurul Huda \\ ${ }^{2}$ STKIP Nurul Huda \\ *E-mail: enggar@stkipnurulhuda.co.id
}

\begin{abstract}
Abstrak
Penelitian eksperimen ini dilakukan di SDN Ulak Buntar. Untuk mengetahui perbedaan hasil belajar siswa pada mata pelajaran IPA sebelum dan sesudah tindakan (menerapkan metode pembelajaran Tari Bambu). Teknik pengambilan sampelnya dengan sample random sampling, sedangkan teknik analisis data menggunakan uji t untuk dua sampel kecil yang satu sama lain saling berhubungan. Hasil penelitian yang dibahas adalah hasil belajar siswa pada mata pelajaran IPA materi perubahan lingkungan mengalami peningkatan nilai mean pada pree-test dan post test, yaitu 5,8 (pree-test) meningkat menjadi 7,8 (post-test). Kemudian, ada perbedaan yang signifikan antara hasil belajar siswa pada mata pelajaran IPA materi perubahan lingkungan. Dengan melihat hasil uji hipotesis yang di dapat dalam perhitungan $\left(\mathrm{t}_{\mathrm{o}}=\right.$ $12,05)$ dan besar $t$ yang tercantum pada table $t\left(t_{\text {t.ts }} 5 \%=2,08\right.$ dan $\left.t_{\text {t.ts }} 1 \%=2,83\right)$ maka dapat diketahui bahwa $t_{0}$ lebih besar daripada $t_{t}$, yaitu $2,09<12,05>2,86$.
\end{abstract}

Kata kunci : Pembelajaran IPA, Metode Tari Bambu.

\section{PENDAHULUAN}

Saat ini dunia pendidikan dihadapkan pada berbagai perubahan dalam berbagai aspek kehidupan dimasyarakat. Hal ini diakibatkan oleh perkembagan ilmu pengetahuan dan teknologi yang begitu pesat, serta globalisasi yang melanda dunia termasuk Indonesia, sehingga dengan kemajuan zaman, tuntutan tersebut terarah kepada apa yang dihasilkan oleh dunia pendidikan yaitu untuk menghadapi ilmu globalisasi yang semakin membutuhkan Sumber Daya Manusia (SDM) yang berkualitas (Arief, 2010). Salah satu masalah yang dihadapi oleh dunia pendidikan kita adalah masalah lemahnya dalam peningkatan pemahaman pembelajaran. Dalam belajar anak kurang bersemangat disebabkan anak merasa bosan dengan metodemetode ceramah. Semangat belajar siswa bisa dengan proses metode-metode pembelajaran yang mereka suka tetapi tidak melenceng dari tujuan pembelajaran tersebut. (Dalyono, 2006).

Mengingat pentingnya pelajaran IPA pada sekolah dasar maka diperlukan pembenahan proses pembelajaran yang dilakukan guru yaitu dengan menggunakan suatu metode pembelajaran yang dapat meningkatkan pemahaman siswa dalam belajar sehingga mendapatkan hasil belajar yang lebih baik. Pemilihan metode pembelajaran dalam kegiatan pembelajaran yang tepat akan membuat peserta didik tertarik pada pelajaran tersebut dan tugas guru dalam menyampaikan materi akan lebih mudah dipahami dan tujuan pembelajaran dapat dicapai secara optimal (Riyanto, 2010).

Hasil belajar sangat besar pengaruhnya terhadap prestasi belajar karena apabila bahan pembelajaran yang dipelajari tidak sesuai dengan minat maka siswa tidak akan belajar dengan baik sebab tidak menarik baginya, siswa akan malas belajar dan tidak akan mendapatkan kepuasan dalam pembelajaran tersebut, jika bahan pembelajaran yang dibuat menarik dan memotivasi siswa untuk belajar serta lebih mudah untuk dipelajari ini akan meningkatkan prestasi dan hasil belajar (Dalyono, 2006)

Padapenelitianinitertarikmenggunakanmetodetaribambudikarenakanberdasarkanobservasipeneliti yang dilaksanakan peneliti sebelum menggambil judul ini di SD N Ulak Buntar terdapat permasalahan pada kegiatan pembelajaran yang selama ini guru masih menggunakan metode ceramah, sehingga siswa 
mendengar, memperhatikan dan bertanya tanpa berpartisipasi aktif saat proses pembelajaran sehingga proses belajar mengajar masih kurang efektif dan hasil belajar yang didapat juga masih rendah.

Pengambilan sampel ini berdasarkan hasil belajar siswa pada mata pelajaran IPA yang belum maksimal. Hal ini karena dalam proses pembelajaran selalu menggunakan metode ceramah, sehingga guru yang lebih aktif dan siswa kurang dilibatkan dalam kegiatan pembelajaran, serta kurang termotivasi dan proses pembelajaran yang menjenuhkan, maka hasil belajarnya menjadi rendah di bawah kriteria ketuntasan minimal sekolah

Berdasarkan latar belakang masalah di atas maka penelitian ini bertujuan untuk mengetahui pengaruh penerapan metode tari bambu terhadap hasil belajar siswa pada mata pelajaran IPA di Pendidikan Dasar.

\section{METODE/EKSPERIMEN}

Penelitian ini adalah penelitian eksperimen dengan menggunakan pendekatan kuantitatif. penelitian eksperimen adalah penelitian yang digunakan untuk mencari pengaruh perlakuan tertentu, jenis penelitian ini ada kelas yang diambil sebagai kelas perlakuan, disebut kelas eksperimen dan yang satunya sebagai kelas pembanding atau kelas kontrol. Pendekatan kuantitatif adalah data penelitian berupa angka-angka dan analisis menggunakan statistik (Sugiyono, 2011). Variabel dalam penelitian ini terdiri dari variabel bebas dan variabel terikat. Adapun yang menjadi variabel bebas $(X)$ adalah metode pembelajaran tari bambu dan variabel terikat $(\mathrm{Y})$ adalah hasil belajar siswa.

Populasi target penelitian ini adalah siswa SD N Ulk Buntar Belitang Mulya pada tahun ajaran 2017/2018. Pupulasi pada penelitian ini adalah pada kelas IV yang berjumlah 38 orang. Penarikan sampel ini mengacu pada teknik probability sampling (simple random sampling) karena sampel yang dilakukan pada unit sampling. Sampel pada peneitian ini adalah 20 orang pada kelas IV A sebagai kelas eksperimen.

Pengumpulan data yang dilakukan dalam penelitian ini adalah dengan menggunakan tes dalam bentuk pilhan ganda. menggunakan observasi, dan dokumentasi. Analisis data pada penelitian ini menggunakan rumus statistik tes "T" untuk dua sampel kecil (N kurang dari 30 ), sedangkan kedua sampel kecil ini satu sama lain mempunyai hubungan. Adapun rumus yang digunakan yaitu : (Sudijono, 2010).

$t_{o}=\frac{M_{D}}{S E_{M_{D}}}$

\section{HASIL DAN PEMBAHASAN}

Hasil pretest dan posttest siswa pada materi perubahan lingkungan yang telah diolah dengan menggunakan rumus statistik product moment. dengan rata-rata yang diperoleh pada pretest dan posttest adalah 5,8 dan 7,85. sedangkan standar deviasi pada nilai pretest dan posttest adalah 1,32 dan 1,11.

Perhitungan pengkategorian pretest TSR dapat dilihat pada skala di bawahini:

$5,8+1,32=7,12$ Hasil belajar IPA sebelum diterapkan metode pembelajaran tari bambu di kategorikan tinggi.

Antara 4,48 - 7,12 Hasil belajar IPA sebelum diterapkan metode pembelajaran tari bambu di kategorikan sedang.

$5,8-1,32=4,48$ Hasil belajar IPA sebelum diterapkan metode pembelajaran tari bambu di kategorikan rendah.

Tabel 1. Persentase Hasil Belajar IPA Siswa sebelum Diterapkan Metode Pembelajaran Tari Bambu di SD N Ulak Buntar

\begin{tabular}{clcc}
\hline No & HasilBelajar IPA & Frekuensi & Persentase \\
\hline 1. & Tinggi (Baik) & 1 & $5 \%$ \\
\hline 2. & Sedang & 15 & $75 \%$ \\
\hline
\end{tabular}




\begin{tabular}{cccc}
\hline 3. & Rendah & 4 & $20 \%$ \\
\hline & JUMLAH & 20 & $100 \%$ \\
\hline
\end{tabular}

Perhitunganpengkategorianposttest TSR dapatdilihatpadaskala di bawahini:

$7,85+1,11=8,96$ Hasilbelajar IPA sebelumditerapkanmetode pembelajaran tari bambu di kategorikantinggi. Antara6,74 - 8,96Hasilbelajar IPA sebelumditerapkan media bendatiruan di kategorikansedang.

$7,85-1,11=6,74$ Hasilbelajar IPA sebelumditerapkan media bendatiruan di kategorikanrendah.

Tabel 2. PersentaseHasilBelajar IPA SiswasesudahDiterapkanMetode Pembelajaran Tari Bambu di SD N Ulak Buntar

\begin{tabular}{cccc}
\hline No & HasilBelajar IPA & Frekuensi & Persentase \\
\hline 1. & Tinggi (Baik) & 6 & $30 \%$ \\
\hline 2. & Sedang & 13 & $65 \%$ \\
\hline 3. & Rendah & 1 & $5 \%$ \\
\hline & JUMLAH & 20 & $100 \%$ \\
\hline
\end{tabular}

Berdasarkan perhitungan data yang telah dilakukan dari hasil penelitia nmenunjukkan bahwa penerapan metode pembelajaran tari bambu pada mata pelajaran IPA memiliki peningkatan yang cukup baik, jika dilihat rata-rata dari 5,80 sebelum penerapan metode pembelajaran tari bambu menjadi 7,85 setelah penerapan metode tersebut. Dari presentase yang dapat dilihat dari tabel, siswa yang mendapat hasil yang tinggi juga bertambah dari5\% menjadi30\%, sebelum penerapan metode tersebut siswa kurang memperhatikan serta siswa tidak menarik penjelasan dari peneliti dengan keluar masuk ruang kelas atau melihat keadaan luar, tetapi dengan penerapan metode tersebut sisw asangat memperhatikan serta siswa berantusias untuk mengetahui apa yang dijelaskan dan siswa juga banyak bertanya, keingintahuannya sangatlah tinggi. Kemudian pada siswa yang mendapatkan hasil yang sedang juga berkurang dari75\% menjadi $65 \%$, siswa yang perhatiannya kurang pada materi yang diberikan oleh peneliti sebelum penerapan metode, tetapisetelah penerapan tersebut siswa berbeda sekali siswa sudah banyak berubah, yang sebelumnya banyak kegiatan sendiri setelah penerapan tersebut siswa tertarik sehingga mengalami peningkatan. Dan yang mendapatkan hasil yang rendah dari $20 \%$ menjadi $5 \%$, siswa mengalami perubahan dengan penerapan metode tersebut siswa bersemangat untuk menerima materi tersebut, antusias siswa sangat berbeda dengan adanya penerapan metode tersebut yaitu metode pembelajaran tari bambu.

Hipotesis dalam penelitian ini adalah ada atau tidak ada perbedaanya hasil belajar siswa dalam mata pelajaran IPA kelas IV SD N Ulak Buntar sebelum dan sesudah diajarkan menggunakan metode pembelajaran tari bambu. Dengan menggunakan uji kesamaan dua rata-rata, uji dua pihak, diperoleh rumusan hipotesis sebagai berikut:

$\mathrm{H}_{\mathrm{a}} \quad$ Ada perbedaan yang signifikan hasil belajar siswa sebelum dan sesudah penerapan metode pembelajaran tari bambu pada mata pelajaran IPA di SD N Ulak Buntar.

$\mathrm{H}_{0} \quad$ Tidak ada perbedaan yang signifikan hasil belajar siswa sebelum dan sesudah penerapan metode pembelajaran tari bambu pada mata pelajaran IPA di SD N Ulak Buntar.

Uji Statistik tentang berhasil atau tidak penerapan metode pembelajaran tari bambu pada mata pelajaran IPA di SD N Ulak Buntar. Peneliti di sini menggunakan uji statistic dengan rumus product moment dan uji test " $\mathrm{t}$ " untuk mengetahui ada tidaknya perbadingan penerapan metode pembelajaran tari bambu pada mata pelajaran IPA di SD N Ulak Buntar terhadap hasil belajar.

Melihat pada table "r" product moment didapatkan angka df = 18 pada taraf signifikan $5 \%$ adalah 0,468 dan pada taraf signifikan $1 \%$ adalah 0,590 , dengan demikian harga korelasi product moment yang telah diperoleh 0,887 lebih besar dari harga korelasi pada harga nilai, baik pada taraf signifikan $5 \%$ maupun $1 \%$, maka ada korelasi positif yang signifikan antara penggunaan metode pembelajaran tari bambu dengan hasil belajar 
siswa.

Ho ditolak dan Ha dapat diterima. Adapun perbandingan angka kedua jenis korelasi tersebut adalah sebagai berikut:

$0,468<0,887>0,590$

Hal ini menunjukkan bahwa antara penggunaan metode pembelajaran tari bambu terhadap hasil belajar siswa di SD N Ulak Buntar terdapat korelasi yang positif.

Besarnya $t$ yang diperoleh dalam perhitungan $($ to $=12,05)$ dan besarnya $t$ yang tercantum pada table $t$ (tt.ts. $5 \%=2,09$ dan tt.ts. $1 \%=2,86$ ) maka dapat diketahui bahwa to lebih besar daripada tt; yaitu

$2,09<12,05>2,86$

Jadi, karena to lebih besar daripada tt maka hipotesa nihil yang diajukan ditolak, ini berarti bahwa adanya perbedaan yang signifikan hasil belajar siswa SD antara sebelum dan sesudah diterapkan metode pembelajaran tari bambu.

Berdasarkan analisis hasil penelitian dan pembahasan menunjukkan bahwa terdapat perbedaan hasil belajar di kelas setelah melakukan pembelajaran yang menggunakan metode pembelajaran tari bambu. Hal ini disebabkan oleh adanya metode yang membantu siswa dalam memahami materi yang diajarkan oleh guru yang dalam hal ini adalah metode pembelajaran tari bambu. Pembelajaran dengan menggunakan metode pembelajaran tari bambu di kelas suasana belajar yang membuat siswa aktif dan partisipasif, sehingga siswa sangat fokus untuk memperhatikan penjelasan materi yang diberikan tidak melakukan aktivitas yang tidak berguna, siswa antusias dalam proses pembelajaran di kelas serta menyenangkan. Hasil belajar yang diperoleh akan baik disebabkan karena dengan adanya keinginan siswa untuk belajar. Metode pembelajaran juga bisa memberikan rangsangan kepada siswa untuk belajar, menjadikan pembelajaran semakin efektif dan efisien dan dapat mengatasi kebutuhan dan problem siswa dalam belajar.

Selain itu berdasarkan penelitian yang dilakukan Finny Khaeriyah, yang judulnya mirip dengan judul peneliti, tetapi dalam hal itu metode yang diterapkan adalah metode cooperative learning. Hasil penelitiannya membuktikan bahwa metode cooperative learning tersebut dapat meningkatkan hasil belajar siswa dapat dilihat dari siklus I ketuntasan nilai siswa yaitu 40,74\% dan siklus II ketuntasan nilai siswa adalah 81,38\%, serta dapat dibuktikan bahwa dapat meningkatkan hasil belajar siswa dalam pembelajaran.

Penelitian eksperimen yang peneliti lakukan menghasilkan hal-hal baru dalam penelitian antara lain: Para siswa sangat antusias dalam mengikuti pembelajaran IPA dengan menggunakan metode tari bambu tersebut dalam pembelajaran. Penerapan metode pembelajaran tai bambu dapat memberikan hasil belajar yang baik jika dibandingkan dengan tidak menggunakan metode tersebut.

\section{PENUTUP}

Berdasarkan hasil penelitian dan pembahasan yang telah disajikan pada bab sebelumnya maka dapat disimpulkan bahwa hasil belajar sebelum penerapan metode pembelajaran tari bambu (pree-test) memiliki rata-rata 5,8. Sedangkan hasil belajar setelah penerapan metode pembelajaran tari bambu (post-test) memiliki rata-rata 7,8. Dengan demikian bahwa metode pembelajaran tari bambu yang telah diterapkan ada perbedaan yang signifikan terhadap hasil belajar siswa pada materi perubahan lingkungan, hal ini dapat dilihat dari hasil uji hipotesis dengan membandingkan besarnya $t$ yang diperoleh dalam perhitungan $\left(\mathrm{t}_{\circ}=\right.$ $12,05)$ dan besarnya $t$ yang tercantum pada table $t\left(t_{\text {t.ts. } 5 \%}=2,09\right.$ dan $\left.t_{t . t s .1 \%}=2,86\right)$ maka dapat diketahui bahwa $t_{0}$ lebih besar daripada $t_{t}$; yaitu $2,09<12,05>2,86$.

Sarannya adalah penerapan metode pembelajaran tari bambu ini dalam penyediaan tidak membutuhkan biaya yang cukup besar serta membutuhkan waktu yang cukup, sehingga semua guru dapat menggunakan metode ini, serta guru juga harus terampil dalam mengatur waktu dalam pembelajaran. Disarankan kepada guru terkhusus guru IPA agar dapat menggunakan metode yang membuat siswa aktif dan partisipasi sehingga dapat menghasilkan pembelajaran yang dapat membuat semangat belajar siswa serta tidak membosankan. Kemudian,disarankan kepada sekolah untuk tetap memotivasi guru agar selalu menerapkan metode pembelajaran yang membuat siswa aktif dan semangat dalam pembelajaran. Bagi semua pendidik teruslah berupaya untuk dapat terampil dalam menggunakan metode pada saat melaksanakan belajar mengajar di kelas. Karena dengan menggunakan metode pembelajaran akan membantu siswa cepat memahami suatu materi yang disampaikan oleh guru serta pembelajaran tersebut lebih menarik dan 
menyenangkan. Segala sesuatu yang dapat mengembangkan kecerdasan para siswa hendaklah pendidik mengusahakannya dengan memberikan pembelajaran yang efektif dan efisien serta hadirkan mereka dalam setiap do'a, agar kegiatan belajar mengajar mendapatkan keberkahaan dunia akhirat. Amin

\section{UCAPAN TERIMAKASIH}

Terimakasih kepada Ketua STKIP Nurul Huda OKUTIMUR, Pembantu Ketua STKIP Nurul Huda OKU TIMUR, Ketua LPPM STKIP Nurul Huda OKUTIMUR, Anggota Jurnal Jemari STKIP Nurul Huda OKUT, Kepala SD N Ulak Buntar beserta jajarannya, Dan Dosen-Dosen STKIP Nurul Huda OKUTIMUR.

\section{DAFTAR PUSTAKA}

Arikunto.2010. Manajemen Penelitian, Bandung: Rineka Cipta. Dalyono, M. 2006. Psikologi Pendidikan: Jakarta: Rineka Cipta. Djamarah. 2002. Psikologi belajar,Jakarta :Rineksa Cipta.

Elymanizar. 2009 Psikologi Pendidikan, Palembang: Rafah Perss.

Rusman. 2010. Model-Model Pembelajaran. Jakarta:RajaGrafindoPersada

Riyanto. 2010. StrategibelajarMengajar. Bandung: PustakaSetia

Sugiyono. 2010. Metode Penelitian Kuantitatif dan Kualitatif dan $R$ dan D. Bandung: Alfabeta.

Khaeriyah, Finny. 2016. Peningkatan Hasil Belajar IImu Pengetahuan Sosial melalui Metode Cooperative Learning Teknik Group Investigasi. Program Pascasarjana UNJ, Jakarta. 